ПУБЛІЧНЕ УПРАВЛІННЯ ТА АДМІНІСТРУВАННЯ

УДК 330.341 .1

https://doi.org/10.35546/kntu2078-4481.2021.4.16

О.О. БОРЗЕНКО

ДУ “Інститут економіки та прогнозування НАН України" ORCID: 0000-0002-1017-5942

О.М. БОЙКО

ДУ “Інститут економіки та прогнозування НАН України" ORCID: 0000-0002-6567-1679

\title{
ДЕРЖАВНЕ РЕГУЛЮВАННЯ НАЦІОНАЛЬНОЮ ЕКОНОМІКОЮ В СУЧАСНИХ РЕАЛІЯХ: ПРОБЛЕМИ ТА ПЕРСПЕКТИВИ
}

У сучасних умовах створення правових, економічних та сочіальних засад економіки відбувається на тлі кризових явищ, тому провідну роль у регулюванні національної економіки відіграє держава, а формування системи державного регулювання залишається однією із найважливіших проблем.

Метою дослідження $\epsilon$ визначення особливостей державного регулювання національною економікою в сучасних реаліях.

У статті здійснено визначення суті, ролі та функиій державного регулювання національної економіки в розрізі основних теоретичних та практичних проблем сучасної економічної науки. Розглянуто основні теоретичні концепції щуодо ролі та функцій держави в економіці, які є елементами сучасного наукового світогляду.

Визначено сутність поняття державного управління. Розкрито особливості державного регулювання національною економікою в світі та в Україні.

Розкрито особливості державного регулювання наукових парків як драйверів економічного зростання національною економікою в сучасних реаліях на інновачійних засадах. Узагальнено досвід особливостей створення та функціонування наукових парків в світі та в Україні. Визначено позитивні аспекти розвитку наукових парків та ризики в Україні.

Розроблено пропозищії щуодо функціонування наукових парків в Україні. Відзначено доцільність використання позитивного досвіду функціонування наукових парків з урахуванням національних особливостей і інтересів.

Ключові слова: державне управління, державне регулювання, неоліберали, наукові парки, спеціальні форми організації інноваційної діяльності.

Е.А. БОРЗЕНКО

ГУ “Институт экономики и прогнозирования НАН Украины” ORCID: 0000-0002-1017-5942

Е.Н. БОЙКО

ГУ “Институт экономики и прогнозирования НАН Украины” ORCID: 0000-0002-6567-1679

\section{ГОСУДАРСТВЕННОЕ РЕГУЛИРОВАНИЕ НАЦИОНАЛЬНОЙ ЭКОНОМИКОЙ В СОВРЕМЕННЫХ РЕАЛИЯХ: ПРОБЛЕМЫ И ПЕРСПЕКТИВЫ}

В современных условиях создание правовых, экономических и социальных устоев экономики происходит на фоне кризисных явлений, поэтому ведущую роль в регулировании национальной экономикой играет государство, а формирование системы государственного регулирования остается одной из важнейших проблем.

Целью исследования является определение особенностей государственного регулирования национальной экономикой в современных реалиях.

В статье определены сущцность, роль и функции государственного регулирования национальной экономикой в разрезе основных теоретических и практических проблем современной экономической науки. Рассмотрены основные теоретические концепции роли и функций государства в экономике, которые являются элементами современного научного мировоззрения.

Определена сущность понятия государственного управления. Раскрыты особенности государственного регулирования национальной экономикой в мире и Украине.

Раскрыты особенности государственного регулирования научных парков как драйверов экономического роста национальной экономикой в современных реалиях на инновационных началах. 
Обобщен опыт особенностей создания и функиионирования научных парков в мире и Украине. Определены положительные аспекты развития научных парков и риски в Украине.

Разработаны предложения по функционированию научных парков в Украине. Отмечена целесообразность использования положительного опыта функционирования научных парков с учетом национальных особенностей и интересов.

Ключевые слова: государственное управление, государственное регулирование, неолибераль, научные парки, специиальные формы организации инновационной деятельности.

O. BORZENKO

SO "Institute of Economics and prediction of NAS of Ukraine" ORCID: 0000-0002-1017-5942

O. BOIKO

SO "Institute of Economics and prediction of NAS of Ukraine" ORCID: 0000-0002-6567-1679

\section{STATE REGULATION OF THE NATIONAL ECONOMY IN MODERN REALITIES: PROBLEMS AND PROSPECTS}

In modern conditions, the creation of legal, economic and social foundations of the economy takes place against the background of crises, so the leading role in regulating the national economy is played by the state, and the formation of state regulation remains one of the most important problems.

The purpose of the study is to determine the features of state regulation of the national economy in modern realities.

The article defines the essence, role and functions of state regulation of the national economy in terms of the main theoretical and practical problems of modern economics. The main theoretical concepts of the role and functions of the state in the economy, which are elements of the modern scientific worldview, are considered.

The essence of the concept of public administration is determined. Peculiarities of state regulation of the national economy in the world and in Ukraine are revealed.

The peculiarities of state regulation of science parks as drivers of economic growth by the national economy in modern realities on an innovative basis are revealed. The experience of the peculiarities of the creation and functioning of science parks in the world and in Ukraine is generalized. The positive aspects of the development of science parks and risks in Ukraine have been identified.

Proposals for the functioning of science parks in Ukraine have been developed. The expediency of using the positive experience of functioning of science parks in Ukraine taking into account national peculiarities and interests is noted.

Key words: public administration, state regulation, neoliberals, science parks, special forms of organizing innovation.

\section{Постановка проблеми}

В сучасних реаліях розвитку національної економіки відбувається складний період формування правових, економічних, соціальних основ. Тому, з метою подолання кризових явищ провідну роль відіграє державне регулювання економіки, формування системи якого є однією 3 найважливіших проблем.

У системі економічних та управлінських наук “Державне регулювання економіки” займає особливе місце, оскільки 3 одного боку, державне регулювання економіки $є$ складовою економічної теорії, в якій представлено механізм регулювання економіки як цілісної соціально-економічної системи. 3 іншого боку - для державного регулювання економіки притаманний механізм застосування форм, методів та інструментів вирішення проблем конкретної національної економіки. При цьому державне регулювання не не вузькоспеціалізований, а загальноекономічний характер, адже охоплює безліч питань з макро- та мікроекономіки, багатьох економічних та управлінських дисциплін.

\section{Аналіз останніх досліджень і публікацій}

Питання державного управління i державного регулювання національної економікою в сучасних реаліях досліджували такі фахівці як проводили Е. Адельсеітова, О. Бойко-Бойчук, В. Гриньова, Л. Дідківська, В. Малиновський, Т. Піхняк, І. Розпутенко, Р. Рудницька, Д. Стеченко, О. Федорчак, Н. Харченко та інші.

Особливості інноваційної діяльності, у тому числі за рахунок державного регуювання наукових парків висвітлювали у своїх наукових працях такі видатні фахівці, як В. Андріанов, У. Андрусов, А. Асаул, В. Баронов, А. Бовін, Ю. Брушко, Н. Гальчинський, А. Гончаров, Д. Дмитрієв, В. Євтушин, І. Єгоров, Л. Загвойська, Н. Зубаревич, С. Іванов, Г. Костюнін, В. Ляшенко, О. Молдован, А. Новіков, С. Приходько, К. Рудий, Д. Санатов, А. Селіванов, С. Соколенко, В. Якимович та ін.

\section{Формулювання мети дослідження}


Метою дослідження $\epsilon$ визначення особливостей державного регулювання національної економікою, у тому числі з врахуванням особливостей міжнародного досвіду функціонування наукових парків, як однієї зі спеціальних форм організації інноваційної діяльності.

Викладення основного матеріалу дослідження

У визначенні поняття державного регулювання мають бути теоретично виражені загальне i специфічне, характерне для його сутності як політико-адміністративного впливу державних владних інститутів на суспільство. Відповідно до цього підходу можна сформулювати таку дефініцію державного регулювання - це свідомий вплив державних інститутів на діяльність суспільства, його окремих груп, в яких реалізуються суспільні потреби і інтереси, загальнозначущі цілі і воля суспільства.

Державне регулювання - це разом $з$ тим самоврядування відносно самої держави і соціальної системи в цілому, де діють стихійні регулятори суспільних процесів, що не охоплені раціональної діяльністю держави. У науковій літературі і практиці державних органів поряд 3 поняттям "державне регулювання" використовується поняття "державне управління", причому береться до уваги їх істотна смислова відмінність. 3 точки зору неолібералів, допустиме, наприклад, в обмежених рамках державне регулювання економіки, але виключається державне управління економікою і соціальними процесами [1]. Семантичне трактування термінів не завжди відповідає сучасній практиці їх функціонування. Поняття "управління" означає переважно зовнішній (що йде від суб'єкта) цілепокладальний вплив на систему, що є фактором збереження і стимулювання певної спрямованості саморозвитку системи.

Регулювання передбачає створення необхідних умов для спонтанної дії внутрішніх закономірностей і механізмів системи, наприклад для попередження конфліктів або примирення конфліктуючих сторін.

Також є слушною думка, що між державним управлінням і державним регулюванням немає принципових відмінностей за цільовим призначенням. По суті справи, регулювання - неодмінний елемент державного управління. Теорія соціального управління описала два типи механізмів регуляції поведінки людей в суспільстві: 1) свідома; 2) стихійна [2].

Свідоме регулювання і є соціальним, зокрема й державне управління. Суть стихійного механізму - в спонтанному, мимовільному (автоматичному) регулюванні процесів поведінки і діяльності соціальних суб'єктів, що не потребують втручання державних або інших керуючих сил. Відзначимо одне з важливих методологічних положень про місце і роль державного управління: державне управління як раціональна, цілепокладальна діяльність суспільства щодо самоврядування.

Спонтанна саморегуляція суспільного життя також $\epsilon$ необхідною формою i аспектом самоврядування соціальної і політичної систем. Наука соціального управління та світова практика довели, що в міру ускладнення суспільних і політичних систем зростає роль раціональних механізмів регуляції, включаючи державне управління. Водночас не припиняють діяти і відігравати свою роль механізми спонтанного (стихійного) регулювання.

Система державного регулювання, що застосовується в сучасній Україні, має незавершений характер. Об'єктивна можливість проводити державне регулювання національної економіки з'являється 3 досягненням певного рівня економічного розвитку, концентрації виробництва і капіталу. Необхідність, що перетворює цю можливість в реальність, обумовлена наростанням проблем і труднощів. Державне регулювання сучасної економіки $є$ складовою частиною процесу відтворення, вирішує завдання стимулювання економічного зростання, регулювання зайнятості, заохочення прогресивних зрушень у галузевій і регіональній структурі, полягає в підтримці експорту. Конкретні напрями, форми, масштаби державного регулювання національною економікою визначаються характером і гостротою економічних $\mathrm{i}$ соціальних проблем в тій чи іншій країні в конкретний період [3].

Найбільш розвинений механізм регулювання сформувався в деяких державах Західної Європи (у Франції, у ФРН, Нідерландах, скандинавських країнах, Австрії, Іспанії), а також в Японії і низці країн Азії і Латинської Америки, що швидко розвиваються. Менш розвинене державне регулювання національної економіки в США, Канаді, Австралії, де на відміну від Європи не було соціальноекономічних потрясінь, таких як Друга світова війна, утворення, а потім розпад табору соціалізму. Крім того, приватний капітал у цих країнах мав особливо сильні позиції. Проте регулювання і тут відіграє помітну роль, переважно в періоди погіршення кон'юнктури і високих показників безробіття й інфляції.

Цікавим з точки зору вивчення механізму регулювання є злиття суб'єктів державної та приватної економічної політики і виникнення в результаті цього нових регулюючих органів, що не вписуються теоретично в класичну схему парламентської або президентської республіки. Формуються комітети, ради 3 підтримки або розвитку окремих галузей, представників міністерства економіки і галузевих спілок підприємців. Зворотний зв'язок між процесом регулювання економіки і носіями господарських інтересів досить жорсткий [4].

До об'єктів державного регулювання національною економікою прийнято відносити регіони, галузі, де виникли або можуть виникнути труднощі, проблеми, які не вирішуються автоматично або належно не вирішуються тривалий час. 
Одним з об'єктів державного регулювання інноваційної діяльності $є$ наукові парки, які зосереджені у багатьох країнах світу (Бельгія, Бразилія, Велика Британія, Ізраїль, Індія, Італія, Китай, Малайзія, США, Таїланд, Японія, Франція, Швейцарія, Україна тощо). Одним з найперших наукових парків є "Кремнієва долина" (США), на території якого зосереджені високотехнологічні компанії 3 виробництва комп'ютерів, їх складових, а також приладів мобільного зв'язку, біотехнологій тощо. Це понад 20 найбільших світових компаній, серед яких “Apple”, “Cisco", “3Com”, "Google”, "Sun”, "Yahoo" тощо [5-6].

Іншим прикладом є науковий парк “Шосе - 128” (США), який спеціалізується на розвитку електронної промисловості. На території наукового парку функціонує 4000 підприємств, а чисельність працівників становить 250 тис. осіб. Реалізація проектів підтримується державними програмами "Вибір на користь конкурентоспроможності", а також “Федеральне партнерство розширення виробництва", основною метою яких є поширення високих технологій в традиційних галузях промисловості.

Ще одним цікавим прикладом інноваційного розвитку є діяльність “Трикутного дослідного парку” (США), на території якого зосереджено 40 підприємств, а чисельність працюючих становить 27 тис. осіб. У рамках наукового парку діють 5 видів податкових пільг, які сприяють промисловому зростанню, а також 14 видів допомоги промисловим підприємствам (проведення ННТР, навчання і перекваліфікація персоналу, придбання модернізованого обладнання тощо).

Важливим є вже набутий досвід діяльності наукового парку “Чжунгуаньцунь” (КНР), розташований на території Академії наук КНР, Пекінського університету, Політехнічного університету та інших відомих інститутів. На території наукового парку зосереджена інформаційна промислова база “Шанді”, експериментальна база “Юнфєн”, а також “Фєнтаюань”, “Чанпіньюань”, “Ічжуань”. Кількість підприємств становить понад 8 тис. одиниць, серед яких левову частку (понад 50,0\%) складають підприємства з випуску електроніки.

Що ж стосується України, то за даними Міністерства освіти і науки України на території України функціонує 36 наукових парків (Корпорація "Науковий парк Київський університет імені Тараса Шевченка", Корпорація "Науковий парк Миколаївського національного аграрного університету "АГРОПЕРСПЕКТИВА", Науковий парк "Інноваційно-інвестиційний кластер Тернопілля", Науковий парк "ФЕД", Науковий парк "Синергія", Науковий парк "Наукоград - Харків", Науковий парк Національного університету біоресурсів і природокористування "Стале природокористування та якість життя", Товариство з обмеженою відповідальністю "Науковий парк Київського національного економічного університету", Товариство з обмеженою відповідальністю "Науковий парк "Аерокосмічні інноваційні технології", Товариство 3 обмеженою відповідальністю "Науковий парк "Енергоефективні технології", Товариство з обмеженою відповідальністю "Науковий парк "Профілактична медицина та охорона праці - новітні системи та технології", Товариство 3 обмеженою відповідальністю "Науковий парк "Біометричний інноваційно-технологічний кластер "БІТеК", Товариство 3 обмеженою відповідальністю "Науковий парк "Центр трансферу технологій цивільного захисту", Товариство 3 обмеженою відповідальністю "Науковий парк Одеського політехнічного університету", Товариство 3 обмеженою відповідальністю "Науковий парк "Прикарпатський університет", Науковий парк товариства 3 обмеженою відповідальністю "Науковий парк Національного технічного університету "Харківський політехнічний інститут", Товариство з обмеженою відповідальністю "Науковий парк «ДонНУ- Поділля", Товариство 3 обмеженою відповідальністю "Науковий парк Державної екологічної академії післядипломної освіти та управління "ЧОРНОБИЛЬ", Товариство 3 обмеженою відповідальністю "Науковий парк "Хімічні технології", Товариство 3 обмеженою відповідальністю "Науковий парк Ужгородський національний університет", Науковий парк "Київська політехніка", Товариство 3 обмеженою відповідальністю "Науковий парк "Агрозоовет", Товариство з обмеженою відповідальністю "Науковий парк Одеського державного аграрного університету", Товариство 3 обмеженою відповідальністю "Науковий парк "КАРДІО ПЛЮС", Товариство 3 обмеженою відповідальністю "Науковий парк Таврійського національного університету імені В. І. Вернадського "Університетський Арсенал", Товариство з обмеженою відповідальністю "Науковий парк Херсонської державної морської академії "Інновації морської індустрії", Товариство 3 обмеженою відповідальністю "Науковий парк Львівського університету "Інновації та підприємництво", Науковий парк "Наука і безпека", Товариство 3 обмеженою відповідальністю "Науковий парк Національної металургійної академії України", Товариство 3 обмеженою відповідальністю "Науковий парк університетів "Інноваційні технології та кібербезпека", Товариство $з$ обмеженою відповідальністю "Науковий парк Національного університету "Львівська політехніка", Товариство з обмеженою відповідальністю "Науковий парк Національного авіаційного університету", Товариство з обмеженою відповідальністю "Міжнародний медичний науковий парк", Товариство з обмеженою відповідальністю "Науковий парк "AgroUnity", Товариство 3 обмеженою відповідальністю "Науковий парк "Надійний трубопровідний транспорт енергоносіїв", Товариство 3 обмеженою відповідальністю "Науковий парк Сумського національного аграрного університету").

Сучасна ситуація в сфері функціонування наукових парків як спеціальних форм інноваційної 
діяльності в Україні характеризується наявністю проблем, що вимагають термінового прийняття рішень. Зокрема, найбільш важливими 3 них $є$ : недосконалість договірно-правових відносин в частині регулювання питань використання земельних ділянок державної та комунальної власності, на яких можуть бути створені наукові парки (в частині використання виключно договорів оренди землі); відсутність чітко встановленого переліку видів діяльності, які доцільно впроваджувати в межах наукового парку; недосконалість норм чинного законодавства, зокрема - в частині визначення оптимальних форм стимулювання залучення інвестицій, необхідних для облаштування наукових парків шляхом звільнення від сплати ввізного мита на обладнання, устаткування та комплектуючих до них матеріалів та ін. Зазначені проблеми потребують термінового вирішення.

Як свідчить світовий досвід, вирізняють декілька моделей функціонування наукових парків, серед яких [5-7]:

- “Американська" (в основу покладено механізм державного фінансування та використання інвестицій юридичних осіб; нововведення розробляються до стадії технічного прототипу; застосовується незначна орендна плата за землю, споруди, доступ до лабораторного обладнання та послуг). За такою моделлю функціонують наукові парки, створені у США та Великій Британії.

- "Японська" (наукові парки створено за рахунок залучення коштів держави; розташовані у великих містах, загальна площа яких становить не більше $500 \mathrm{~m}^{2}$; на території наукового парку зосереджено науково-промислові комплекси, університети, науково-дослідні інститути; $є$ розвинена культурна, рекреаційна та транспортна інфраструктура). Дана модель наукових парків функціонує на території Японії.

- “Змішана" (поєднує особливості розвитку наукових парків за “американською” та “японською” моделями). Особливості функціонування даної моделі простежуються на території Франції.

Процес формування наукових парків характеризується проявом двох фаз: інституціональної створюється господарська (готелі, підприємства, магазини та ресторани, банки) та дослідницька інфраструктури; підприємницької - розпочинається через декілька років після інституційної фази [7]. Остання фаза вирізняється економічним зростанням функціонування наукового парку (створюються нові робочі місця, виникають інкубатори бізнесу та дрібні інноваційні компанії, спостерігається функціонування консультативних та обслуговуючих організацій).

До основних джерел фінансування функціонування наукового парку необхідно віднести: кошти статутного та інших джерел наукового парку; фінансові надходження від діяльності наукового парку; інвестиції, надані науковому парку; благодійні внески для розвитку наукового парку та забезпечення реалізації проектів наукового парку; кошти державного та місцевого бюджетів; кошти замовників; інші надходження, не заборонені законодавством будь-якої країни. Найбільш перспективним у сучасних умовах України вважаємо підхід до створення та розвитку наукових парків на основі на використання коштів 3 державного та місцевого бюджетів. У Великій Британії такі джерела становлять 62,0 \%, Німеччині - 78 \%, Франції - 74,0 \%, Нідерландах - близько 70,0 \% та Бельгії - близько 100,0\% [8].

Розглянемо пропозиції щодо вибору інструментів підтримки розвитку наукових парків. Верховною Радою України прийнято рамковий Закон України “Про наукові парки” №1563-VI від 25.06.2009 р., який визначає правові, організаційні та економічні засади створення і функціонування наукових парків на території України [15]. Законом передбачено державне замовлення на поставку науковими парками продукції, виконання робіт і надання послуг для забезпечення пріоритетних державних потреб; залучення коштів державного та місцевого бюджетів та ін. Передбачені механізми державної підтримки в період затяжної економічної рецесії, відсутності державних ресурсів для функціонування наукових парків носять суто декларативний характер. Однак, внесення змін до Закону та їх реалізація сприятиме позитивному розвитку наукових парків, як одній зі спеціальних форм інноваційної діяльності в Україні.

Підтримуючи законодавчі ініціативи, спрямовані на підвищення ефективності вітчизняної науки i, створення цивілізованих механізмів використання результатів наукової діяльності 3 метою забезпечення економічних і суспільних потреб, розроблено пропозиції до проєкту Закону про внесення змін до деяких законодавчих актів України щодо діяльності наукових парків (реєстр №4236 від 20.10.2020 р.). Звертаємо увагу на певні недоліки, присутні у даному законопроєкті, зокрема у Законі України “Про наукові парки”№1563-VI від 25.06.2009 р.:

1. Вважаємо за доцільне здійснити доповнення у статтю 1. Визначення термінів Розділу I Загальні положення, ст. 1 Визначення термінів, зокрема доцільно було б внести такі поняття, як:

“- замовники продукції наукового парку - установи, організації, підприємства, вітчизняні та іноземні компанії будь-якої форми власності, які замовляють та сплачують виконання розробок чи послуг відповідно до проекту наукового парку;

- транснаціональний науковий парк - науковий парк, який створюється та функціонує на основі міжнародного договору України, укладеного між урядами країн або уповноваженими засновниками його 
створення. Порядок створення та розвитку транснаціонального наукового парку регулюється міжнародними договорами України”.

2. У Розділі I Загальні положення, зокрема поняття ст. 1 Визначення термінів надається визначення терміну проект наукового парку - “пакет документів, що визначає процедуру і комплекс необхідних заходів щодо розроблення, створення та реалізації інноваційного продукту чи інноваційної продукції і містить дані про матеріально-технічні, фінансові, кадрові ресурси, необхідні для виконання науковим парком та його партнерами проекту наукового парку згідно з вимогами цього Закону”. При цьому необхідно зазначити, що в Законі України “Про інноваційну діяльність” в Розділі I Загальні положення, зокрема поняття ст. 1 Визначення термінів також $є$ визначення терміну інноваційний проект - “комплект документів, що визначає процедуру і комплекс усіх необхідних заходів (у тому числі інвестиційних) щодо створення і реалізації інноваційного продукту і (або) інноваційної продукції”, тому відповідні терміни потребують уніфікації.

3. У статтю 2. Законодавство про науковий парк в Розділ I Загальні положення додати пункт “2. Якщо міжнародним договором України, згода на обов'язковість якого надана Верховною Радою України, встановлено інші правила, ніж ті, що передбачені цим Законом, застосовуються правила міжнародного договору України".

4. У Розділі II Оптимізаційні засади створення та діяльності наукового парку є ст. 3. Мета створення наукового парку в якій зазначено, що “Науковий парк створюється з метою розвитку науковотехнічної та інноваційної діяльності у вищому навчальному закладі та/або науковій установі, ефективного та раціонального використання наявного наукового потенціалу, матеріально-технічної бази для комерціалізації результатів наукових досліджень і їх впровадження на вітчизняному та закордонному ринках". В ст. 1 Визначення термінів пропонується надати визначення терміну “комерціалізація результатів науково-технічної діяльності — діяльність, спрямована на перетворення об’єктів права інтелектуальної власності у продукти чи послуги для їх реалізації на ринку з метою отримання доходу, надання ліцензії чи передачу за договором прав на їх використання іншим суб'єктам господарювання або використання їх у власній господарській діяльності наукового парку”. Відповідні терміни потребують уніфікації. Також необхідно зазначити, що у запропонованому вигляді відповідний термін не використовується в подальшому у тексті Закону.

5. У Розділ II Організаційні засади створення та діяльності наукового парку необхідно внести:

“Статтю 14. Перелік документів для включення наукового парку до Реєстру наукових парків України”, у якій необхідно зазначити наступне:

1. Включення наукового парку до Реєстру наукових парків України потребує, щоб засновник наукового парку подав до уповноваженого державного органу наступні документи: 1) заяву про включення наукового парку до Реєстру наукових парків України; 2) рішення засновника про створення наукового парку; 3) концепцію розвитку наукового парку; 4) найменування партнерів наукового парку (за наявності).

Статтю 15. Рішення про включення наукового парку до Реєстру наукових парків України

1. Розгляд поданої заяви засновником наукового парку та доданих до неї документів здійснюється уповноваженим державним органом протягом 30 календарних днів 3 дня їх надходження. Уповноважений державний орган приймає рішення про включення або вмотивовану відмову у включенні наукового парку до Реєстру наукових парків за результатами розгляду документів.

2. Прийняття рішення про включення наукового парку до Реєстру наукових парків України базується на основі врахування таких критеріїв, як: 1) доступність трудових ресурсів, необхідних для функціонування наукового парку відповідно до концепції розвитку; 2) наявність та/або можливість залучення засновником наукового парку фінансових, матеріально-технічних та інших ресурсів, необхідних для його розвитку у відповідності з концепцією; 3) підтримка наукового парку з боку органів місцевого самоврядування та місцевих органів виконавчої влади; 4) наявність підписаних меморандумів про наміри та/або договорів $з$ партнерами наукового парку.

3. У рішенні про включення наукового парку до Реєстру наукових парків України зазначається: 1) назва наукового парку; 2) засновник наукового парку; 3) строк, на який створено науковий парк; 4) місцезнаходження, площа на яких створено науковий парк.

4. Уповноважений державний орган зобов'язаний протягом трьох робочих днів 3 дня прийняття рішення про включення наукового парку до Реєстру наукових парків України письмово повідомити центральний орган виконавчої влади, що реалізує державну податкову політику та політику у сфері державної митної справи, та відповідні місцеві державні адміністрації про засновника, партнерів наукового парку.

Статтю 16. Концепція функціонування наукового парку

1. Засновник наукового парку зобов’язаний розробити і затвердити концепцію розвитку, в якій зазначаються: 1) назва наукового парку; 2) засновник наукового парку; 3) мета, завдання створення та функціональне призначення наукового парку; 4) місце розташування та площу; 5) строк, на який 
створюється науковий парк; 6) вимоги до партнерів наукового парку; 7) план розвитку наукового парку; 8) орієнтовні ресурси (фінансові, матеріальні, технічні, трудові, природні тощо), необхідні для створення та розвитку наукового парку, очікувані джерела їх залучення; 9) очікувані результати функціонування наукового парку; 10) інші відомості на розсуд засновника наукового парку; 11) організаційна модель функціонування наукового парку.

2. Концепція функціонування наукового парку затверджується засновником відповідного парку, шляхом прийняття рішення."

5. Потребує доповнення ст. 4. Функції наукового парку пунктом “2. Функціональне призначення наукового парку визначається Концепцією відповідного наукового парку”, оскільки основні функції наукового парку у Законі є розпливчатими.

6. Також потребує внесення змін ст. 5. Установчі документи Розділу II Організаційні засади створення та діяльності наукового парку - пункт 2 замінити пунктом “4. Істотними умовами договору про створення наукового парку є: предмет договору, строк договору, порядок та умови здійснення наукової діяльності у межах наукового парку, порядок та умови залучення партнерів наукового парку, правовий режим майна, створеного засновником наукового парку, а також переданого для використання майна, що є власністю засновника; склад та порядок надання звітності уповноваженому державному органу; порядок набрання чинності цим договором з дня його підписання".

“Невід’ємними частинами договору про створення та функціонування наукового парку є:

рішення про створення наукового парку;

концепція наукового парку;

бізнес-план науково парку”.

7. Запропонований припис «Науковий парк повинен мати програму розвитку, де визначаються мета, пріоритети, стратегічні цілі, конкретні кроки щодо їх реалізації, очікувані результати та показники їх виконання» у ст. 5. Установчі документи наукового парку Розділу II Організаційні засади створення та діяльності наукового парку на жаль не дозволяє встановити такі дії, як ким і коли буде розроблена $\mathrm{i}$ затверджена програма розвитку наукового парку.

8. На наш погляд потребує внесення нового пункту Стаття 7. Створення наукового парку у частині того, що наукові парки повинні забезпечувати оприлюднення визначеної чинним законодавством інформації про свою діяльність, окрім інформації з обмеженим доступом. Також про їх створення та діяльність суспільство повинно бути проінформоване. Тому пропонуємо внести пункт 6. у наступному трактуванні: “Інформація про створені наукові парки $є$ публічною, доступ до неї забезпечує уповноважений державний орган, шляхом іiї розміщення на своєму офіційному веб-сайті.

Для надання державної підтримки, передбаченої законодавством, уповноважений державний орган створює, веде та розміщує на своєму офіційному веб-сайті Реєстр наукових парків України. До нього наукові парки включаються за згодою засновника наукового парку.

Майнові права інтелектуальної власності на Реєстр наукового парку України (бази даних) належать державі в особі уповноваженого державного органу. Держава, органи державної влади та їх посадові особи користуються Реєстром наукових парків України (базою даних) на безоплатній основі. На майнові права на комп'ютерні програми та бази даних для ведення Реєстру наукових парків України поширюються вимоги ст. 18. Фінансове та інше забезпечення надання адміністративних послуг Закону України “Про адміністративні послуги” (5203-17).

Державна підтримка надається засновникам наукового парку, партнерам наукового парку, включеним до Реєстру наукових парків України."

9. У Законі на нашу думку потребує додаткового роз'яснення положення Статті 17. Майнові права на технології та об'єкти права інтелектуальної власності Розділу IV Державна підтримка діяльності наукових парків щодо можливостей центрального органу виконавчої влади... на обмеження майнових прав “на використання і розпорядження технологій та об'єктів права інтелектуальної власності, створених із залученням державних коштів, у разі якщо технологію та/або об'єкт права інтелектуальної власності: .....визнано таким, що мають використовуватися в публічних інтересах" та ін.

10. Доповнити ст. 19. Особливості оподаткування ввізним митом наукового, лабораторного i дослідницького обладнання, комплектуючих та матеріалів для виконання проектів наукових парків пунктом 2 наступного змісту: “Суб'єкти господарювання, які звільняються від ввізного мита наукового, лабораторного і дослідницького обладнання, комплектуючих та матеріалів для виконання проектів наукових парків у зв'язку 3 провадженням діяльності відповідно до цього Закону, зобов'язані щоквартально публікувати інформацію на власному сайті, офіційному друкованому органу місцевого самоврядування щодо отриманих податкових пільг та звільнення ввід сплати податку, їх розміру та напрямки використання зазначених коштів.”

11. У пункті 7. До джерел фінансування наукового парку ст. 21. Майнові відносини та фінансування наукового парку Розділу V Економічні засади діяльності наукового парку наведено перелік джерел фінансування, який окрім виокремлених повинен бути ширшим і містити такі статті, як 
“фінансові надходженні від партнерів, замовників наукового парку та інших юридичних осіб; кошти приватних інвесторів, у тому числі залучені за моделлю державно-приватного партнерства; залучені кошти, включаючи кредити банків та інших фінансово-кредитних установ.”

У Закон України «Про освіту» (2145-19) “статтю 81. Державно-приватне партнерство у сфері освіти і науки пункт 3. Державно-приватне партнерство у сфері освіти і науки може передбачати: утворення та/або спільне фінансування і експлуатацію ...” додати “наукових парків та інших форм інноваційних підприємств" [16], а потім продовжити існуючим текстом “(інноваційний центр, технопарк, технополіс, інноваційний бізнес-інкубатор тощо) на базі існуючих закладів освіти” та додати новий текст "і науки".

У Закон України «Про наукову і науково-технічну діяльність» (848-19) до статті 60. Участь державних наукових установ, державних вищих навчальних закладів у створенні господарських товариств з метою використання об’єктів права інтелектуальної власності пункту 1. “Державні наукові установи (крім державних наукових установ оборонно-промислового комплексу), державні університети, академії, інститути,...” необхідно додати “...а також утворені ними відповідно до Закону наукові парки та інші форми інноваційних підприємств", продовжуючи зміст існуючим текстом у законі “мають право бути засновниками та співзасновниками господарських товариств та беруть участь у формуванні статутного капіталу такого господарського товариства виключно шляхом внесення до нього майнових прав інтелектуальної власності, виключні майнові права на які зберігаються за державною науковою установою або державним університетом, академією, інститутом".

Проєкт Закону про внесення змін до деяких законодавчих актів України щодо діяльності наукових парків (реєстр №4236 від 20.10.2020р.) з урахуванням висловлених зауважень і пропозицій експертами у галузі створення та розвитку наукових парків був прийнятий у другому читанні 07.09.2021 p. 3 практичної точки зору у новій редакції Закону надається право: створювати наукові парки без узгодження з Міністерством освіти і науки України, а також самостійно визначати напрями своєї діяльності; право бути засновниками кількох наукових парків; можливість надавати в оренду приміщення для розміщення наукових парків на пільгових умовах (1 грн. орендної плати за 1 квадратний метр орендованої площі).

Висновки
Система державного регулювання, що застосовується в сучасній Україні, має незавершений характер. Об'єктивна можливість проводити державне регулювання національної економіки з'являється з досягненням певного рівня економічного розвитку, концентрації виробництва і капіталу. Необхідність, що перетворює цю можливість в реальність, обумовлена наростанням проблем і труднощів. Державне регулювання сучасної економіки є складовою частиною процесу відтворення, вирішує завдання стимулювання економічного зростання, регулювання зайнятості, заохочення прогресивних зрушень у галузевій і регіональній структурі, полягає в підтримці експорту. Конкретні напрями, форми, масштаби державного регулювання національною економікою визначаються характером і гостротою економічних i соціальних проблем в тій чи іншій країні в конкретний період.

В результаті проведеного аналізу світового досвіду створення та розвитку наукових парків, необхідно зазначити, що в багатьох країнах світу приділяють функціонуванню наукових парків значну увагу. Їх діяльність сприяє перетворенню результатів науково-технічних робіт в нові конкурентоспроможні товари, послуги, підготовці висококваліфікованих фахівців для інноваційної діяльності, створенню малих і середніх інноваційних підприємств, зменшенню інноваційного циклу від ідеї до товару та ін. Позитивний досвід функціонування наукових парків може бути використано щодо їх розвитку в Україні з урахуванням національних особливостей і інтересів.

\section{Список використаної літератури}

1. Державне регулювання економіки та економічна політика [Текст]: навч. посіб. / Г. С. Третяк, К. М. Бліщук. Львів : ЛРІДУ НАДУ, 2011. 128 с.

2. Адамовська В. С. Механізм державного регулювання економіки та вибір напряму економічної політики в сучасних умовах господарювання. Державне управління: удосконалення та розвиток. 2017. № 4.

3. Світові моделі державного управління: досвід для України / за заг. ред. Ю. В. Ковбасюка, С. В. Загороднюка, П. І. Крайніка, Х. М. Дейнеги. Київ: НАДУ, 2012. 612 с.

4. Тарнавська О.Б. Особливості державного регулювання в умовах трансформації економіки України. Науковий вісник ЛНУВМБТ імені С.З. Гжицького, 2016. т. 18. № 2 (69). URL: https://core.ac.uk/download/pdf/235838493.pdf

5. Миролюбова Т.В., Суханова П.А. Зарубежный опит развития инновационной инфраструктуры университетов в региональных инновационных системах // Фундаментальные исследования. - 2013. №1. - C.215-220. 
6. Порівняння особливостей технологічних парків [Електронний ресурс]. - Доступний $3:$ http : // www. ekonomikam.com/ecfins-292-1.html

7. Научные парки: новая форма объединения науки и производства // Международные обзоры: клиническая практика и здоровье. - 2013. - №4. - С.134-144.

8. Закон України "Про наукові парки" [Електронний ресурс]. - Доступний 3 : http : // www. zakon2.rada.gov.ua/laws/show/1563-17

9. Закон України "Про вищу освіту” [Електронний ресурс]. - Доступний 3 : http : // www. zakon3.rada.gov.ua/laws/1556-18

10.Закон України "Про інвестиційну діяльність" [Електронний ресурс]. - Доступний 3 : http : // www. zakon3.rada.gov.ua/laws/show/1560-12/

11. Закон України “Про інноваційну діяльність" [Електронний ресурс]. - Доступний $3:$ http : // www. zakon2.rada.gov.ua/laws/show/40-15

12.Закон України "Про державне регулювання діяльності у сфері трансферу технологій" [Електронний ресурс]. - Доступний 3 : http : // www.zakon2.rada.gov.ua/laws/show/143-v

13. Господарський кодекс України [Електронний ресурс]. - Доступний 3 : http : // www.zakon3.rada.gov.ua/laws/436-15 http://zakon3.rada.gov.ua/laws/436-15

14.Цивільний кодекс України [Електронний ресурс]. - Доступний 3 : http : // www.zakon3.rada.gov.ua/laws/show/435-15

15. “Інноваційне підприємство (інноваційний центр, технопарк, технополіс, інноваційний бізнесінкубатор тощо) - підприємство (об'єднання підприємств), що розробляє, виробляє і реалізує інноваційні продукти і (або) продукцію чи послуги, обсяг яких у грошовому вимірі перевищує 70 відсотків його загального обсягу продукції і (або) послуг" ЗАКОН УКРАЇНИ "Про інноваційну діяльність” - Доступний 3 : http://zakon3.rada.gov.ua/laws/show/40-15

\section{Reference}

1. Derzhavne rehulyuvannya ekonomiky ta ekonomichna polityka [Tekst]: navch. posib. / H. S. Tretyak, K. M. Blishchuk. L'viv : LRIDU NADU, 2011. 128 p.

2. Adamovs'ka V. S. Mekhanizm derzhavnoho rehulyuvannya ekonomiky ta vybir napryamu ekonomichnoyi polityky v suchasnykh umovakh hospodaryuvannya. Derzhavne upravlinnya: udoskonalennya ta rozvytok. 2017. № 4.

3. Svitovi modeli derzhavnoho upravlinnya: dosvid dlya Ukrayiny / za zah. red. YU. V. Kovbasyuka, S. V. Zahorodnyuka, P. I. Kraynika, KH. M. Deynehy. Kyyiv: NADU, 2012. 612 p.

4. Tarnavs'ka O.B. Osoblyvosti derzhavnoho rehulyuvannya v umovakh transformatsiyi ekonomiky Ukrayiny. Naukovyy visnyk LNUVMBT imeni S.Z. Gzhyts'koho, 2016. t. 18. № 2 (69). URL: https://core.ac.uk/download/pdf/235838493.pdf

5. Myrolyubova T.V., Sukhanova P.A. Zarubezhnyy opyt razvytyya ynnovatsyonnoy ynfrastruktury unyversytetov v rehyonal'nykh ynnovatsyonnykh systemakh // Fundamental'nye yssledovanyya. - 2013. - №1. pp.215-220.

6. Porivnyannya osoblyvostey tekhnolohichnykh parkiv [Elektronnyy resurs]. - Dostupnyy z : http : // www. ekonomikam.com/ecfins-292-1.html

7. Nauchnye parky: novaya forma ob"edynenyya nauky y proyzvodstva // Mezhdunarodnye obzory: klynycheskaya praktyka y zdorov'e. - 2013. - №4. - pp.134-144.

8. Zakon Ukrayiny "Pro naukovi parky" [Elektronnyy resurs]. - Dostupnyy z : http : // www. zakon2.rada.gov.ua/laws/show/1563-17

9. Zakon Ukrayiny "Pro vyshchu osvitu" [Elektronnyy resurs]. - Dostupnyy z : http : // www. zakon3.rada.gov.ua/laws/1556-18

10. Zakon Ukrayiny "Pro investytsiynu diyal'nist" [Elektronnyy resurs]. - Dostupnyy z : http : // www. zakon3.rada.gov.ua/laws/show/1560-12/

11. Zakon Ukrayiny "Pro innovatsiynu diyal'nist" [Elektronnyy resurs]. - Dostupnyy z : http : // www. zakon2.rada.gov.ua/laws/show/40-15

12. Zakon Ukrayiny "Pro derzhavne rehulyuvannya diyal'nosti u sferi transferu tekhnolohiy" [Elektronnyy resurs]. - Dostupnyy z : http : // www.zakon2.rada.gov.ua/laws/show/143-v

13. Hospodars'kyy kodeks Ukrayiny [Elektronnyy resurs]. - Dostupnyy z : http : // www.zakon3.rada.gov.ua/laws/436-15 http://zakon3.rada.gov.ua/laws/436-15

14. Tsyvil'nyy kodeks Ukrayiny [Elektronnyy resurs]. - Dostupnyy z : http : // www.zakon3.rada.gov.ua/laws/show/435-15

15. "Innovatsiyne pidpryyemstvo (innovatsiynyy tsentr, tekhnopark, tekhnopolis, innovatsiynyy biznesinkubator toshcho) - pidpryyemstvo (ob'yednannya pidpryyemstv), shcho rozroblyaye, vyroblyaye i realizuye innovatsiyni produkty i (abo) produktsiyu chy posluhy, obsyah yakykh u hroshovomu vymiri perevyshchuye 70 vidsotkiv yoho zahal'noho obsyahu produktsiyi i (abo) posluh" ZAKON UKRAYINY "Pro innovatsiynu diyal'nist"' - Dostupnyy z : http://zakon3.rada.gov.ua/laws/show/40-15 